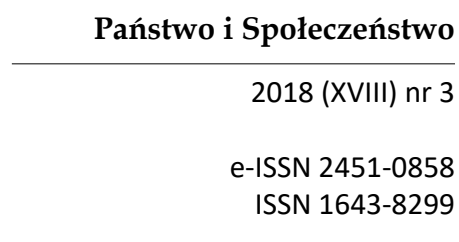

doi.org/10.31749/pismzp2018/20846

\author{
Anna M. Roszkowska \\ Krakowska Akademia im. Andrzeja Frycza Modrzewskiego, \\ Wydział Lekarski i Nauk o Zdrowiu, Katedra Okulistyki
}

\title{
AKTUALNOŚCI W DIAGNOSTYCE I LECZENIU STOŻKA ROGÓWKI
}

\author{
Autor korespondencyjny: \\ Krakowska Akademia im. Andrzeja Frycza Modrzewskiego, Wydział Lekarski i Nauk \\ o Zdrowiu, Katedra Okulistyki, \\ ul. G. Herlinga Grudzińskiego 1, 30-705 Kraków \\ e-mail: aroszkowska@afm.edu.pl
}

\section{Streszczenie}

Stożek rogówki jest chorobą degeneracyjną, polegającą na postępującym ścieńczeniu i uwypukleniu rogówki. Choroba ta, w postaciach zaawansowanych, prowadzi do znacznych zaburzeń ostrości wzroku - jedynym rozwiązaniem staje się wówczas przeszczep rogówki. Nowoczesna diagnostyka stożka bazuje na analizie powierzchni rogówki przy użyciu topo-tomografii komputerowej, która pozwala na ocenę wczesnych zmian chorobowych z możliwością wdrożenia odpowiedniego leczenia w stadiach początkowych. Taką procedurą jest wprowadzone $\mathrm{w}$ ostatnich latach sieciowanie włókien kolagenowych. Zabieg ten, dzięki reakcji fotochemicznej wywołanej oddziaływaniem UVA i ryboflawiny, prowadzi do tworzenia nowych wiązań pomiędzy łańcuchami kolagenu, z następującym usztywnieniem miąższu rogówki i zahamowaniem rozwoju stożka. Wczesna diagnoza, możliwa dzięki obrazowaniu rogówki przy użyciu nowoczesnych systemów topo-tomograficznych w połączeniu z efektywnym zabiegiem powstrzymującym rozwój stożka, stanowią istotne osiągniecie ostatnich lat.

Słowa kluczowe: stożek rogówki, rogówka, topografia rogówki, pachymetria, sieciowanie włókien kolagenowych 


\section{Wprowadzenie}

Stożek rogówki jest chorobą degeneracyjną, charakteryzującą się postępującym ścieńczeniem i uwypukleniem rogówki powodującym obniżenie ostrości wzroku na skutek astygmatyzmu nieregularnego [1]. Schorzenie to do niedawna uważane było za niezapalne, jednak badania ostatnich lat wykazały jego związek z aktywnością cytokin i enzymów prozapalnych w rogówce i na powierzchni oka $[2,3]$. W zaawansowanych postaciach choroby dochodzi do znaczącego obniżenia ostrości wzroku - wówczas jedynym rozwiązaniem terapeutycznym jest przeszczep rogówki.

\section{Epidemiologia i etiopatogeneza stożka}

Opisana w literaturze częstotliwość występowania stożka rogówki waha się pomiędzy 54,5 a 265 przypadków na 100000 osób, a roczna zapadalność to 2-23 przypadków na 100000 [2-4]. Stożek rogówki występuje z jednakową częstotliwością u kobiet i mężczyzn; postępuje do ok. 40 roku życia i jest zazwyczaj obustronny z różnym stopniem zaawansowania.

Etiologia jest do dnia dzisiejszego nieznana. Uważa się, iż na powstanie stożka mogą wpływać drobne urazy, częste pocieranie oka i alergie, czyli wszystkie stany, w których dochodzi do uwalniania prozapalnych cytokin nabłonkowych przyczyniających się do apoptozy keratocytów rogówki, co leży u podłoża zmian zaobserwowanych w stożku. Zmniejszeniu liczby keratocytów wraz z obniżeniem ilości blaszek kolagenowych towarzyszy degradacja fibroblastów miąższu rogówki. Ścieńczenie miąższu, typowe dla tej choroby, spowodowane jest wzrostem aktywności proteaz z jednoczesnym zmniejszeniem aktywności ich inhibitorów, co powoduje obniżenie stabilności biomechanicznej rogówki i jej postępujące uwypuklenie [2,5].

Szczególne znaczenie w etiopatogenezie stożka przypisywane jest predyspozycjom genetycznym, za czym przemawia występowanie rodzinne, wysoka zgodność u bliźniąt jednojajowych i współwystępowanie w niektórych chorobach genetycznych takich jak zespół Marfana, Ehlersa-Danlosa czy Downa [1-4].

Opublikowane w ostatnich latach badania naukowe potwierdzają rolę czynników genetycznych w patogenezie stożka [6-9]; wydaje się, że ich współdziałanie z czynnikami środowiskowymi ma istotne znaczenie w rozwoju choroby.

\section{Objawy}

Objawy subiektywne stożka rogówki to postępujące pogorszenie ostrości wzroku, spowodowane astygmatyzmem i krótkowzrocznością, częste podrażnienia, 
zespół suchego oka oraz, nierzadko, nadwrażliwość na światło. Typowymi zaburzeniami widzenia zgłaszanymi przez chorych są objawy typu „halo” wokół źródła światła, rozmycie konturów, widzenie podwójne.

Objawy kliniczne stożka są dosyć charakterystyczne. W stopniach zaawansowanych może pojawić się tzw. objaw Munsona, polegający na deformacji brzegu powieki dolnej przy spojrzeniu w dół [1-4].

\section{Diagnostyka}

W badaniu przy użyciu lampy szczelinowej obserwuje się typowe dla tego schorzenia ścieńczenie miąższu rogówki w jej części centralnej i paracentralnej odpowiadającej szczytowi stożka (rycina 1).

Pozostałe zmiany rogówki to:

- pierścień Fleischera koloru brunatnego, spowodowany odkładaniem hemosyderyny pod nabłonkiem u podstawy stożka;

- pęknięcia błony Bowmana, a w ich efekcie - blizny podnabłonkowe

- linie Vogta, czyli pionowe linie na szczycie stożka w miąższu rogówki spowodowane rozstępami w istocie właściwej;

- obrzęk rogówki i zaznaczone blizny w stożkach wysoce zaawansowanych [1-3].

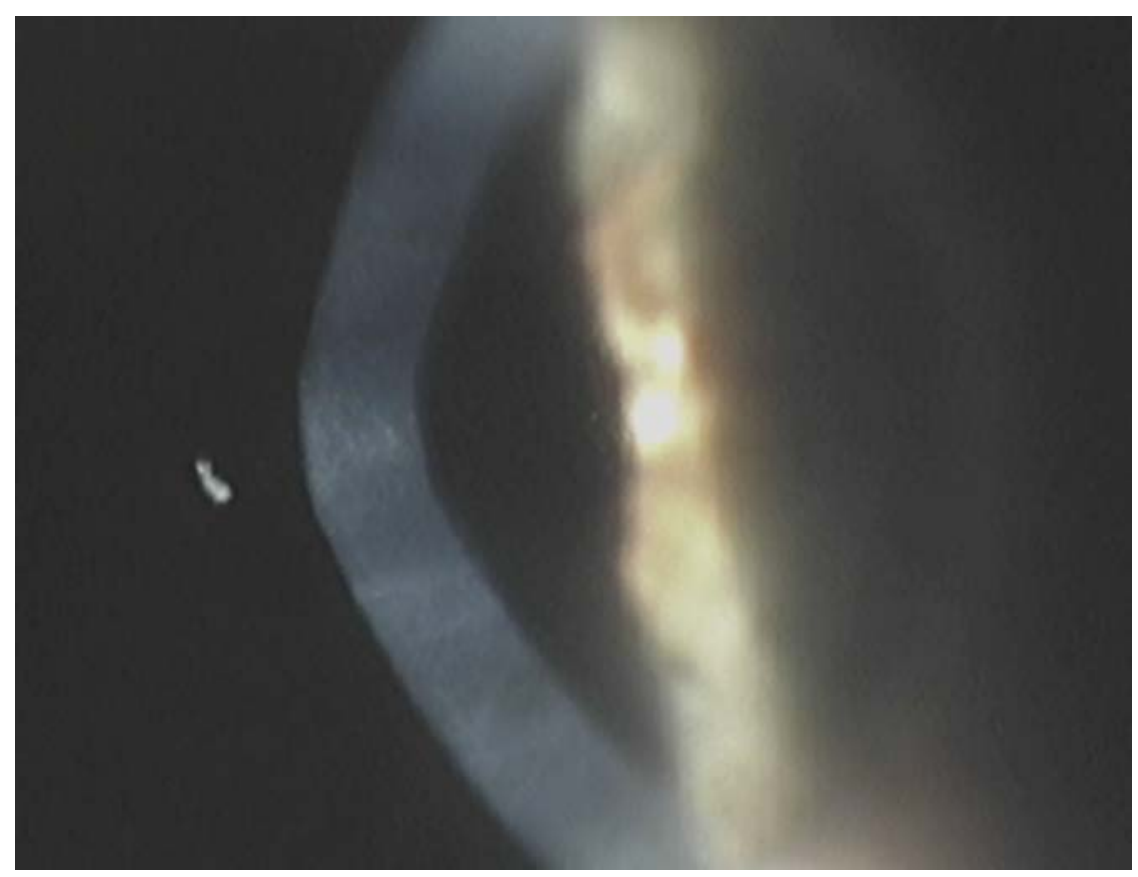

Rycina 1. Stożek rogówki w stanie zaawansowanym

Wszystkie ryciny pochodzą ze zbiorów autora. 
Podstawowym badaniem diagnostycznym w stożku pozostaje komputerowa topografia rogówki, która pozwala na pomiar całkowitej krzywizny jej przedniej powierzchni. Do czasu pojawienia się tej techniki obrazowania informacji o krzywiźnie rogówki dostarczał keratometr, dokonujący pomiaru jedynie w jej części centralnej. Jest więc oczywiste, że takie pomiary w przypadkach wczesnego stożka nie pozwalały na postawienie diagnozy, która była możliwa dopiero w stadiach zaawansowanych.

Jak już wspomniano, współczesne topografy mierzą przednią krzywiznę rogówki w każdym jej punkcie, wykorzystując zmodernizowany dysk Placido, mający postać tarczy z koncentrycznymi pierścieniami - na przemian białymi i czarnymi. Obraz pierścieni po odbiciu od powierzchni rogówki jest analizowany komputerowo przy pomocy odpowiednich algorytmów. Otrzymane dane przetwarzane są na promienie krzywizny i przedstawiane za pomocą barwnych map, w których kolory tzw. ciepłe (od pomarańczowego po czerwony) odpowiadają wzrostowi krzywizny, a kolory zimne (jak ciemnozielony, niebieski, granatowy) charakteryzują obszary o niskiej krzywiźnie. Kolory zielony i żółty zarezerwowane są dla wartości normalnych, najczęściej występujących w populacji (rycina 2,3). Topografia komputerowa pozwala zatem na ocenę krzywizny rogówki oraz informuje o jej kształcie i właściwościach refrakcyjnych [10,11].

Wszystkie topografy są dotowane programami do screeningu stożka poprzez analizę krzywizny rogówki i symetrii otrzymanego obrazu. Aktualnie są to systemy bardzo precyzyjne, które podają wskaźniki prawdopodobieństwa występowania stożka $\mathrm{w}$ badanym oku, a w przypadku obecności schorzenia informują o stopniu jego zaawansowania $[11,12]$.

Diagnoza stożka w jego stadiach początkowych, tj. przedklinicznych, była zawsze problematyczna i pomimo istotnych postępów naukowych i technologicznych do dziś istnieją przypadki, w których trudno jest jednoznacznie potwierdzić istnienie schorzenia.

Najnowsze osiągnięcia w dziedzinie diagnostyki instrumentalnej rogówki to topo-tomografy, które podają informacje nie tylko z przedniej, ale również z tylnej powierzchni rogówki, co pozwala na wykrycie wczesnych zmian typowych dla stożka. Instrumenty te działają na zasadzie pomiaru wysokości w stosunku do punktów odniesienia - np. szczelinowa skaningowa tomografia (Orbscan ${ }^{\circledR}$, Bausch \& Lomb, USA) - lub na zasadzie kamery Scheimpfluga, tworzącej trójwymiarowy model matematyczny przedniego odcinka oka (Pentacam ${ }^{\circledR}$ Oculus, Niemcy; Sirius ${ }^{\circledR}$ CSO, Włochy; Gallilei ${ }^{\circledR}$ Ziemer, Szwajcaria). Możliwość pomiaru przedniej i tylnej powierzchni rogówki pozwala na obserwacje minimalnych zmian w jej grubości i krzywiźnie, które są charakterystyczne dla wczesnych stadiów stożka [13-15] (rycina 4).

Pomiar grubości rogówki stanowi, obok topografii, istotne badanie diagnostyczne w stożku, ponieważ ścieńczenie miąższu towarzyszące wzrostowi krzywizny jest jednym z głównych objawów choroby. Pomiar ten może być wykonywany przy użyciu pachymetrów ultrasonograficznych, jednak informacje 
dotyczące grubości rogówki w każdym jej punkcie, otrzymywane przy użyciu tomografów, są bardziej dokładne, powtarzalne i niezależne od operatora.

Można zatem uznać, że możliwość jednoczesnego pomiaru krzywizny i grubości rogówki w każdym jej punkcie stanowi bez wątpienia istotne osiągnięcie we współczesnej diagnostyce schorzeń rogówki.

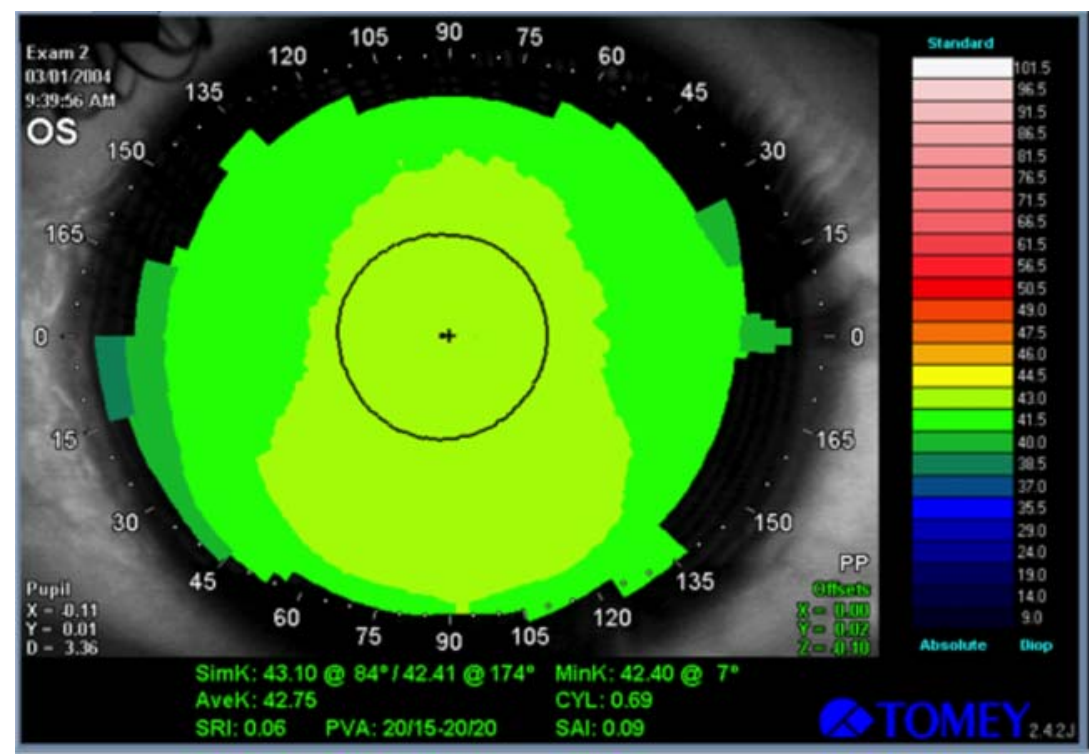

Rycina 2. Topografia rogówki o normalnym profilu

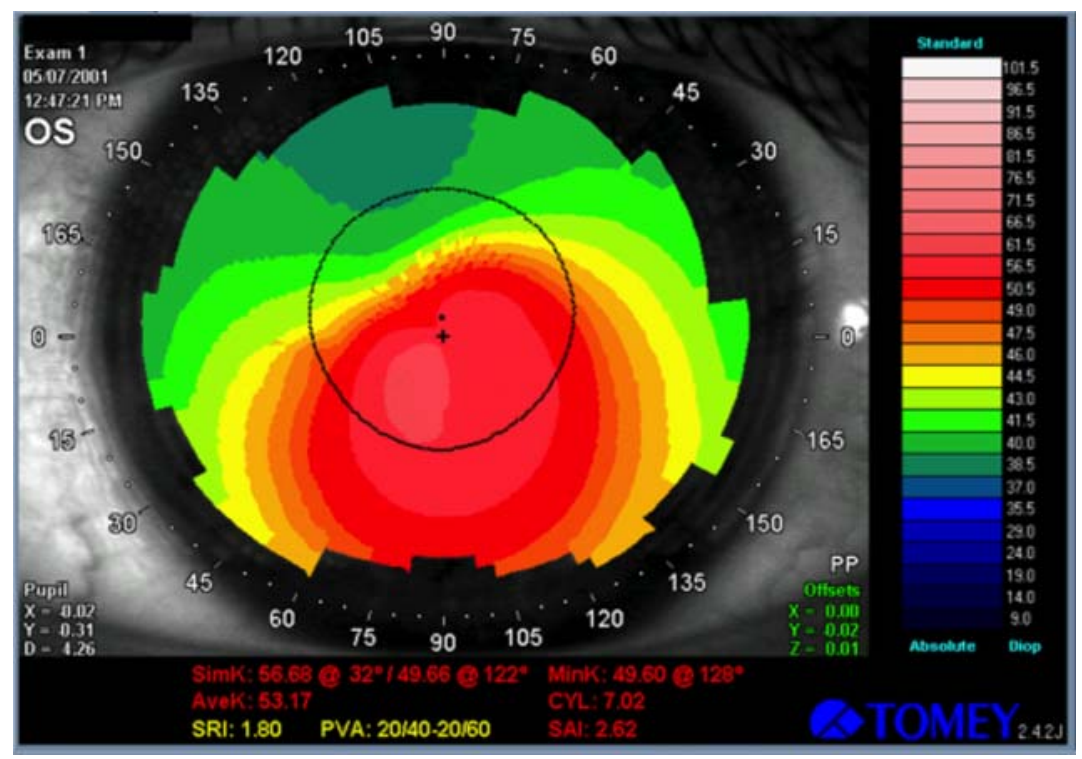

Rycina 3. Topografia rogówki w przypadku stożka rogówki 


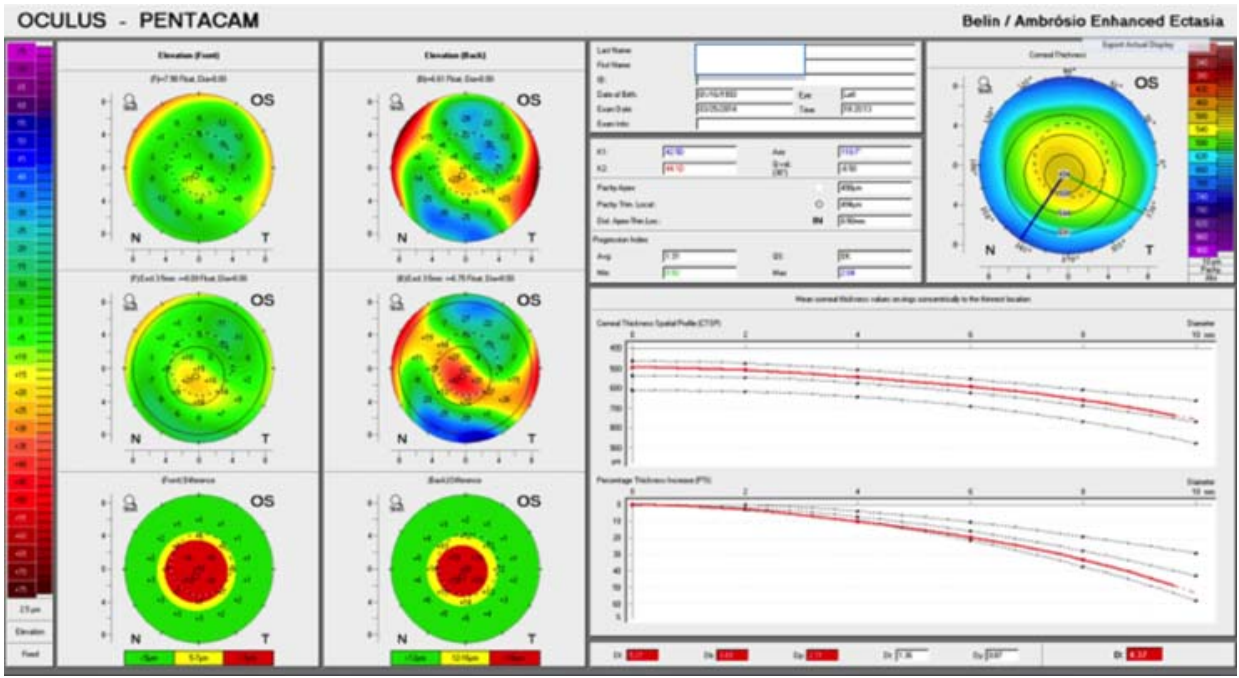

Rycina 4. Przykład analizy wczesnego stożka rogówki przy pomocy programu Belin-Ambrosio Display (BAD), którym dysponuje tomograf Pentacam ${ }^{\circledR}$. U dołu po lewej przedstawiony jest wynik kompleksowej analizy przedniej i tylnej powierzchni rogówki, gdzie istotne zmiany centralnej krzywizny rogówki sugerujące obecność stożka oznaczone są kolorem czerwonym

\section{Klasyfikacja}

Stożek rogówki można sklasyfikować pod względem szybkości rozwoju, jego krzywizny i morfologii. Co do stopnia ewolucji rozróżnia się tzw. forme fruste, czyli stożek nierozwijający się, stożek o rozwoju powolnym, pojawiający się u dorosłych, oraz formy o szybkiej progresji manifestujące się w okresie pokwitania.

Klasyfikacja oparta na wartości krzywizny centralnej stożka (K), która determinuje jej moc łamiącą $\mathrm{w}$ danym punkcie, rozróżnia stożek nieznaczny o wartości $\mathrm{K}<45$ dioptrii, umiarkowany ( $\mathrm{K}: 45-52$ dioptrii), zaawansowany $(\mathrm{K}>52$ dioptrii) i bardzo zaawansowany ( $\mathrm{K}>62$ dioptrii). Klasyfikacja morfologiczna rozróżnia stożek okrągły, owalny i ogólny [2].

Istnieje wiele propozycji podziału stożka pod względem zaawansowania, jednak najbardziej rozpowszechniona jest 4-stopniowa klasyfikacja Amslera-Krumeicha, biorąca pod uwagę średnią krzywizny z mapy topograficznej, refrakcję, grubość oraz przejrzystość rogówki [15]. 


\section{Leczenie}

Leczenie stożka rogówki można podzielić na zachowawcze i chirurgiczne. Pierwsze polega na optycznej korekcji wady wzroku przy pomocy okularów czy odpowiednio dobranych szkieł kontaktowych. W niektórych przypadkach, po odpowiedniej kwalifikacji, istnieje możliwość wykonania laserowej korekcji wady wzroku, jednak takie podejście terapeutyczne nie jest szczególnie rozpowszechnione [16,17].Leczenie chirurgiczne polega przede wszystkim na przeszczepie rogówki, który może być warstwowy lub drążący - w zależności od stopnia zaawansowania stożka i przejrzystości miąższu. Innym zabiegiem mającym na celu poprawę widzenia jest wszczepienie pierścieni śródrogówkowych, które, regulując krzywiznę centralnej części rogówki, poprawiają ostrość wzroku.

W ostatnim dziesięcioleciu nastąpił istotny postęp w leczeniu stożka rogówki. Związane jest to z zastosowaniem zabiegu sieciowania włókien kolagenowych, który powoduje utwardzenie i zwiększenie stabilności rogówki. Sieciowanie włókien kolagenowych rogówki (Corneal Cross-linking) zostało wprowadzone do kliniki przez Theo Seilera i Eberharda Spoerla, badaczy z Uniwersytetu w Dreźnie, w 1998 roku. Zabieg ten, dzięki reakcji fotochemicznej wywołanej działaniem promieniowania UVA o długości fali $370 \mathrm{~nm}$ i ryboflawiny (witaminy B2) na włókna kolagenowe, doprowadza do powstania nowych wiązań pomiędzy łańcuchami kolagenu, które modyfikują jego strukturę i powodują zwiększenie sztywności tkanki. Wybór ryboflawiny nie jest przypadkowy, gdyż ta okazała się idealnym fotouczulaczem, absorbującym UVA o długości fali $370 \mathrm{~nm}$ i wywołującym pożądaną reakcję fotochemiczną, doprowadzającą do powstawania nowych wiązań kolagenowych, co klinicznie objawia się właśnie wzrostem sztywności tkanki rogówki. Usztywnienie miąższu rogówki powstrzymuje proces jej uwypuklania związany z zaburzeniem struktury i nadmierną elastycznością [18-20].

Istnieją różne techniki sieciowania, różniące się sposobem nasączania miąższu rogówki ryboflawiną i czasem naświetlania. Istotne jest optymalne nasączenie i naświetlanie promieniowaniem UVA o mocy $3 \mathrm{~mW} / \mathrm{cm}^{2}$ przez $30 \mathrm{~min}$. lub $10 \mathrm{~mW} / \mathrm{cm}^{2}$ przez 9 min.; taka dawka jest niezbędna do osiągnięcia efektu sieciowania, prowadzącego do zwiększenia stabilności biomechanicznej rogówki i zahamowania procesu chorobowego, jednocześnie zabieg taki pozostaje bezpieczny dla struktur oka (rycina 5).

Rozpowszechnienie zabiegu sieciowania włókien kolagenowych i efektywność tej techniki w zahamowaniu procesu chorobowego doprowadzily w ostatnich latach do istotnego obniżenia ilości przeszczepów rogówki z powodu stożka [21-24].

Należy podkreślić istotne znaczenie wczesnego wykrycia stożka, gdyż po-

zwala ono na zastosowanie zabiegu sieciowania i zahamowanie rozwoju choroby w stadiach początkowych, w których ostrość wzroku jest zachowana lub tylko 
nieznacznie obniżona. Sieciowanie jest zabiegiem o stosunkowo niskiej częstotliwości powikłań, które obserwuje się głównie w technice przewidującej usunięcie nabłonka. Najczęściej występującym powikłaniem jest zaburzenie przejrzystości rogówki, które występuje w 8,6\% przypadków, lecz dotyczy głównie stożków bardziej zaawansowanych. Rzadziej obserwuje się przejściowy obrzęk rogówki lub zakażenia związane z ubytkiem nabłonka i stosowaniem opatrunkowych szkieł kontaktowych [25].

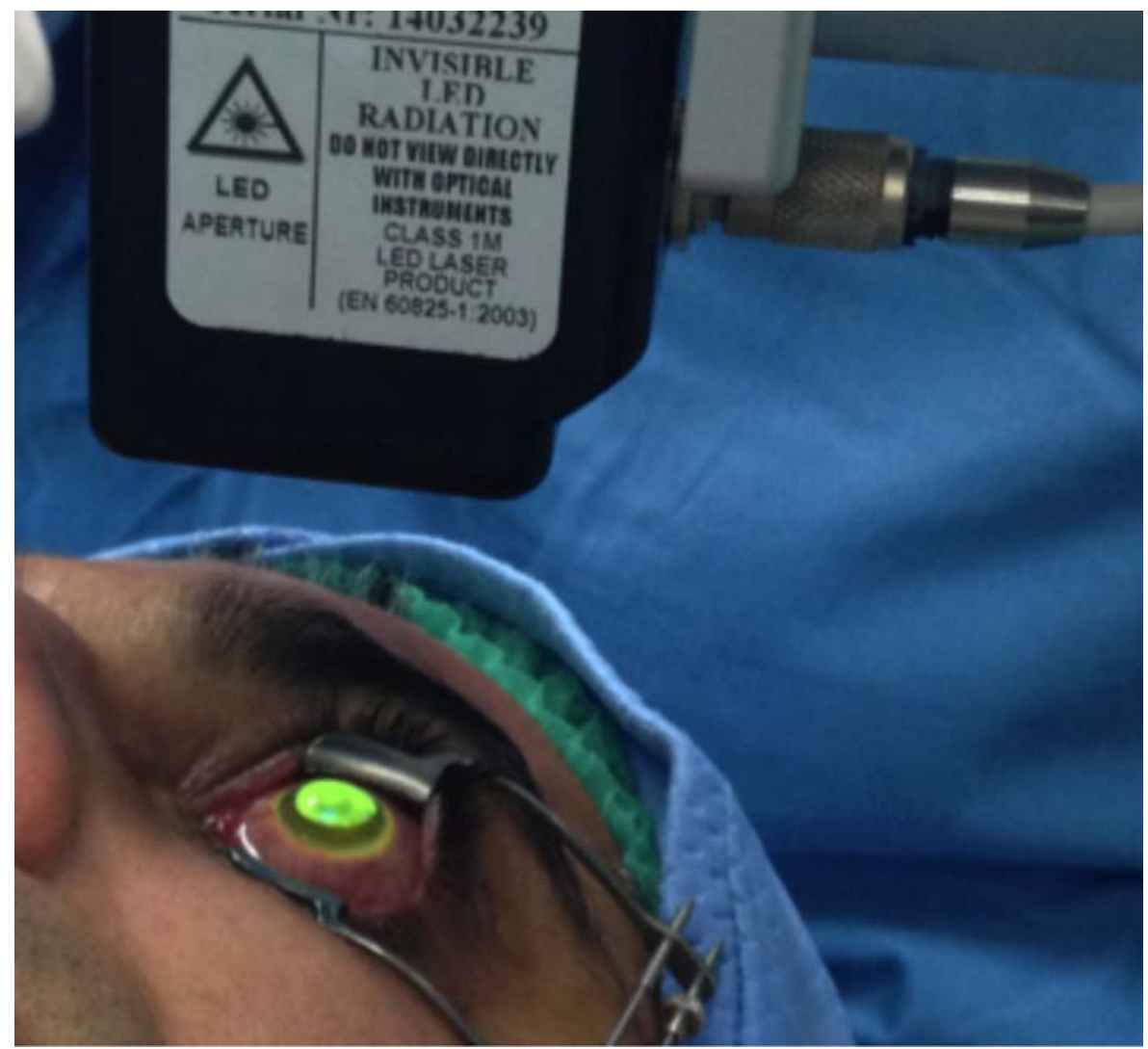

Rycina 5. Zabieg sieciowania włókien kolagenowych

\section{Podsumowanie}

Postępy w diagnostyce stożka rogówki związane są z charakteryzującym ostatnie lata znacznym rozwojem nowoczesnych technologii: zaczynając od keratometru, mierzącego jedynie centralną krzywiznę rogówki, poprzez wideokeratoskopy, aż do nowoczesnych systemów topo-tomograficznych, które wykonują pomiar krzywizny i grubości rogówki w każdym jej punkcie. 
Postępy w leczeniu stożka wynikają bez wątpienia z rozpowszechnienia sieciowania włókien kolagenowych, które okazało się zabiegiem efektywnym, pozwalającym na zahamowanie procesu chorobowego. Rezultatem tego jest znaczny spadek ilości przeszczepów rogówki w krajach, w których procedura ta zaczęła być stosowana rutynowo.

Podsumowując, można stwierdzić, że stożek rogówki jest chorobą występującą częściej niż zwykło się uważać, może mieć przebieg powolny lub przeciwnie: szybki i agresywny, zwłaszcza gdy pojawi się w okresie dojrzewania. Jeżeli nie zostanie zdiagnozowany we wczesnych stadiach, prowadzi do poważnych zaburzeń ostrości wzroku. Istotnym osiągnięciem ostatnich lat jest możliwość wczesnej diagnozy przy użyciu nowoczesnych tomo-topografów oraz nowa technika terapeutyczna zwana sieciowaniem, w której - dzięki reakcji fotochemicznej wywołanej działaniem promieniowania UVA o długości fali 370 nm i ryboflawiny na włókna kolagenowe - dochodzi do powstawania nowych wiązań pomiędzy łańcuchami kolagenu, które, modyfikując jego strukturę, powodują zwiększenie sztywności tkanki. Pozwala to na zatrzymanie choroby w jej wczesnych stadiach, w których jeszcze nie doszło do zaburzenia ostrości wzroku.

\section{Bibliografia}

1. Rabinowitz YS. Keratoconus. Surv Ophthalmol. 1998; 42: 297-319.

2. Mas-Tur V, MacGregor C, Jayaswal R, O'Brart DPS, Maycock NJR. A Review of Keratoconus: Diagnosis, Pathophysiology and Genetics. Survey of Ophthalmology 2017, doi: 10.1016/j.survophthal.2017.06.009.

3. Davidson AE, Hayes S, Hardcastle AJ, Tuft SJ. The Pathogenesis of Keratoconus. Eye. 2014; 28: 189-195.

4. Duncan JK, Belin MW, Borgstrom M. Assesing Progression of Keratoconus: Novel Tomographic Determinants. Eye and Vision. 2016; 3 (6): 1-9.

5. Meek KM, Tuft SJ, Huang Y et al. Changes in Collagen Orientation and Distribution in Keratoconus Corneas. Invest Ophthalmol Vis Sci. 2005; 46: 1948-1956.

6. Nowak DM, Gajecka M. The Genetics of Keratoconus. Middle East Afr J Ophthalmology. 2011; 18: 2-6.

7. Karolak JA, Gajecka M. Genomic Strategies to Understand Causes of Keratoconus. Mol Genet Genomics. 2017; 292: 251-269.

8. Nowak MD, Gajecka M. Nonrandom Distribution of MiRNAs Gene and Single Nucleotide Variants in Keratoconus Loci. Plos One. 2015, July 15.

9. Bykhovskaya Y, Margines B, Rabinowitz YS. Geetics in Keratoconus: Where We Are?. Eye Vis. 2016; 27: 3-16.

10. Smolek MK, Klyce SD. Current Keratoconus Detection Methods Compared with a Neural Network Approach. Invest Ophthalmo Vis Sci. 1997; 38 (11): 2290-2299.

11. Rabinowitz YS, Rasheed K. KISA\% Index: A Quantitative Videokeratography Algorithm Embodying Minimal Topographic Criteria For Diagnosing Keratoconus. J Cataract Refract Surg. 1999; 25 (10): 1327-1335. 
12. Rabinowitz YS. Videokeratographic Indices to Aid in Screening For Keratoconus. J Refract Surg. 1995; 11: 371-379.

13. Belin MW, Khachikian SS. An Introduction to Understanding Elevation-Based Topography: How Elevation Data Are Displayed - A Review. Clinical and Experiment Ophthalmol. 2009; 37: 14-29.

14. Belin MW, Ambrosio R. Scheimpflug Imaging For Keratoconus and Ectatic Disease. Indian J Ophthalmol. 2013; 61 (8): 401-406.

15. Kamiya K, Ishii R, Shimizu K, Igarashi A. Evaluation of Corneal Elevation, Pachymetry and Keratometry in Keratoconic Eyes with Respect to the Stage of Amsler-Krumeich Classification. Br J Ophthalmol. 2014; 98 (4): 459-463.

16. Sakla H, Altroudi W, Munoz G, Sakla Y. Simultaneous Topography-Guided Photorefractive Keratectomy and Accelerated Corneal Collagen Cross-Linking for Keratoconus. Cornea. 2016; 35 (7): 941-945.

17. Camellin M, Guidotti JM, Arba Mosquera S. Corneal-Wavefront Guided Transepithelial Photorefractive Keratectomy After Corneal Collagen Cross Linking in Keratoconus. J Optom. 2017; 10 (1): 52-62.

18. Spoerl E, Huhle M, Seiler T. Induction of Cross-Links in Corneal Tissue. Exp Eye Res. 1998; 66: 97-103.

19. Spoerl E, Mrochen M, Sliney D et al. Safety of UVA Riboflavin Cross-Linking of the Cornea. Cornea. 2007; 26: 385-389.

20. Wollensak G, Spoerl E, Seiler T. Riboflavin/Ultraviolet-A-Induced Collagen Cross-Linking For the Treatment of Kertatoconus. Am J Ophthalmol. 2003; 135: 620-627.

21. Hashemi H, Seyedian MA, Miraftab M, Fotouhi A, Asgari S. Corneal Collagen Cross-Linking with Riboflavin and Ultraviolet A Irradiation for Keratoconus: Long-Term Results. Ophthalmology. 2013; 120: 1515-1520.

22. McCall AS, Kraft S, Edelhauser HF et al. Mechanisms of Corneal Tissue Cross-Linking in Response to Treatment with Topical Riboflavin and Long-Wavelength Ultraviolet Radiation (UVA). Invest Ophthalmol Vis Sci. 2010; 51: 129-138.

23. Vinciguerra P, Albé E, Frueh BE, Trazza S, Epstein D. Two-Year Corneal Cross-Linking Results in Patients Younger Than 18 Years with Documented Progressive Keratoconus. Am J Ophthalmol. 2012; 154: 520-526.

24. Mastropasqua L. Collagen Cross-Linking: When and How? A Review of the State of the Art. Of the Technique and New Perspectives. Eye and Vision 2015; 2: 19.

25. Mohammadpour M, Masoumi A, Mirghorbani M, Shahraki K, Hashemi H. Updates on Corneal Collagen Cross Linking: Indications, Techniques and Clinical Outcomes. Journal of Current Ophthalmology 2017; 29: 235-247.

\title{
Up to date on diagnosis and treatment of keratoconus
}

\begin{abstract}
Keratoconus is a degenerative disease with progressive thinning and steepening of the cornea. In the advanced stages with severe reduction of visual acuity, a corneal transplantation is required. Modern diagnostic procedures are based on corneal topography and tomography that permit early diagnosis and therapy. Corneal Cross-linking is the modern
\end{abstract}


therapeutic procedure that allows arrest of disease progression with maintenance of good visual acuity if performed in early stages. This therapeutic procedure is based on the photochemical reaction induced by riboflavin and UVA radiation that creates new bonds between collagen fibers that results in stromal stiffening that arrest keratoconus progression. It could be stated that significant achievements in keratoconus management are related to the possibility of early detection due to the modern tomographic systems and possibility of effective treatment with corneal cross linking procedure that arrests progression of ectasia.

$\underline{\text { Key words: }}$ keratoconus, cornea, corneal topography, pachymetry, cross-linking 
